\title{
Chemical profile and antimicrobial potential of essential oils of Cymbopogon citratus (DC.) Stapf, Ocimum basilicum Linn and Aniba rosaeodora Ducke
}

\author{
Perfil químico e potencial antimicrobiano dos óleos essenciais de Cymbopogon citratus (DC.) \\ Stapf, Ocimum basilicum Linn e Aniba rosaeodora Ducke
}

\author{
G. O. Everton*; P. S. Santos Júnior ; R. J. Araújo; A. M. Ferreira; P. R. B. Gomes ; \\ P. V. S. Rosa; A. P. M. Pereira; V. E. Mouchrek Filho \\ Laboratório de Pesquisa e Aplicação de Óleos Essenciais (LOEPAV), Universidade Federal do Maranhão, 65080-805, \\ São Luís-MA, Brazil
}

*gustavooliveiraeverton@gmail.com

(Recebido em 08 de maio de 2020; aceito em 01 de junho de 2020)

\begin{abstract}
The study evaluated the chemical profile, antimicrobial activity and toxicity of essential oils (EOs) of $C$. citratus, O. basilicum and A. rosaeodora. The EOs were extracted by hydrodistillation, the chemical profile was determined using the physicochemical parameters and the chemical composition was obtained by gas chromatography coupled to mass spectrometry (GC-MS). The toxicity assay followed the Artemia salina Leach bioassay. To perform the antimicrobial activity, the Disc Diffusion technique and the Mueller Hinton Broth Dilution (MH) technique were used. The physicochemical parameters of the EOs showed satisfactory results. The major chemical composition of the EO of A. rosaeodora presented linalool (93.60\%), the EO of C. citratus exhibited geranial (43.96\%) and EO of $O$. basilicum found methyl chavicol. All EOs in this study had $\mathrm{LC}_{50}$ between $582 \mathrm{mg} \mathrm{L}^{-1}$ and $282 \mathrm{mg} \mathrm{L}^{-1}$. The antimicrobial activity of EO C. citratus demonstrated inhibition halos for S. aureus of $25 \mathrm{~mm}$ and $25 \mathrm{~mm}$ for E. coli, EO of $O$. basilicum exhibited inhibition halo of $18 \mathrm{~mm}$ for E.coli and $20 \mathrm{~mm}$ for S. aureus and EO of A. rosaeodora presented $11 \mathrm{~mm}$ for E. coli and 15 for $S$. aureus. As the values of MIC and MBC found, the $\mathrm{EO}$ of $O$. basilicum presented a more effective inhibitory action against $S$. aureus. It was concluded that the observed biological potentials encourage the application potentials in the efficiency of the control of pathogenic microorganisms.
\end{abstract}

Keywords: essential oil; antimicrobial; toxicity.

O estudo avaliou o perfil químico, a atividade antimicrobiana e a toxicidade dos óleos essenciais (OE's) de C. citratus, O. basilicum e A. rosaeodora. Os OE's foram extraídos por hidrodestilação, o perfil químico foi determinado através dos parâmetros físico-químicos e a composição química foi obtida por cromatografia gasosa acoplada à espectrometria de massas (CG-EM). O ensaio de toxicidade seguiu o bioensaio com Artemia salina Leach. Para realização da atividade antimicrobiana utilizou-se a técnica de Difusão em Disco e a Diluição em Caldo Mueller Hinton (MH). Os parâmetros físico-químicos os OE's apresentaram resultados satisfatórios. A composição química majoritária do OE de A. rosaeodora apresentou o linalol $(93,60 \%)$, o OE de $C$. citratus exibiu o geranial $(43,96 \%)$ e o OE de $O$. basilicum constatou o metil chavicol. Todos os OE's deste estudo apresentaram $\mathrm{CL}_{50}$ entre $582 \mathrm{mg} \mathrm{L}^{-1}$ a $282 \mathrm{mg} \mathrm{L}^{-1}$. A atividade antimicrobiana do OE $C$. citratus demonstrou halos de inibição para S. aureus de $25 \mathrm{~mm}$ e $25 \mathrm{~mm}$ para E. coli, o OE de O. basilicum exibiu halo de inibição de $18 \mathrm{~mm}$ para E.coli e $20 \mathrm{~mm}$ para S. aureus e o OE de A. rosaeodora apresentou $11 \mathrm{~mm}$ para $E$. coli e 15 para $S$. aureus. Conforme os valores de CIM e CBM constataram, o OE de $O$. basilicum apresentou uma ação inibitória mais eficaz contra $S$. aureus. Conclui-se que os potenciais biológicos observados incentivam os potenciais de aplicação na eficiência do controle de microrganismos patogênicos.

Palavras-chave: óleo essencial; antimicrobiano; toxicidade.

\section{INTRODUCTION}

In agriculture, diseases affecting plants can be caused by fungi, bacteria and viruses, generating great losses of crop yield. Many strategies have been developed to prevent damage caused by these pathogens, such as avoidance techniques, crop rotation, soil management, plant nutrition and use of resistant varieties. In addition, chemicals are widely applied to plantations. However, especially 
in organic farming, it is necessary to replace such products with biological methods of disease control and pests [1].

Thus, compounds derived from plants with antimicrobial activity are increasingly explored for use in the preservation and improvement of food quality [2]. Among the natural products, the essential oils (EOs) stand out as a complex natural mixture of varied chemical composition. Being extracted from aromatic plants, their use as antimicrobial has been highly researched because it is safer substitutes for food conservation in relation to chemical additives [3]. The antimicrobial activity of EOs is usually associated with compounds such as eugenol, allicin, thymol and carvracol, linalool, among others. These active ingredients, due to their hydrophobic characteristics, act by breaking the microbial cell wall, resulting in the loss of its functionality [4-6].

EOs have been used for several decades in the pharmaceutical, cosmetic and, more recently, industries as flavoring, flavorings and natural preservatives by the food industries [7]. In their condition, natural antimicrobials have the potential to be used in the control of microorganisms, reducing the need for additives, controlling contamination in food and improving shelf life extension technologies to eliminate undesirable pathogens and slow down the deterioration of products [8].

Among the plants that have EOs stand out Cymbopogon citratus (DC.) Stapf, Ocimum basilicum Linn and Aniba rosaeodora Ducke. Cymbopogon citratus, known as lemongrass, belonging to the Poaceae family, an herbaceous plant originating in India, is widely distributed in several tropical countries, including Brazil. Popular medicine uses its tea or muffled, prepared from its leaves such as soothing, analgesic, antipyretic, antirheumatic, diuretic and digestive disorders. Through studies it is possible to attribute antimicrobial activity to the geranial and neral major compounds present in their EO [9].

Aniba rosaeodora, known as pink wood, belongs to the Lauraceae family, was discovered in Brazil in 1925, is a species native to the Amazon. In its composition the majority compound present in its EO is linalool, in which it was found in other plants such as Ho-Sho (Cinnamomum camphora L.), a substance responsible for inhibiting the growth of microorganisms. In this sense, EO A. rosaeodora is promising as a source of linalool and it is possible to attribute its antimicrobial activity to its majority compound [10].

Ocimum basilicum, known as basil is a medicinal plant which belongs to the Lamiaceae family, has become important in society for presenting cosmetic use, food and due to its therapeutic properties in the pharmaceutical industry. The antimicrobial activity of EO O. basilicum is associated with its methyl chavicol and linalool constituents, thus widely used in folk medicine in combating bacterial infections [11]. In view of the importance of EOs and studies on their activities, this study determined the chemical profile, antimicrobial activity and toxicity of $C$. citratus, $O$. basilicum and A. rosaeodora.

\section{MATERIALS AND METHODS}

\subsection{Botanical material}

The leaves of $C$. citratus and $O$. basilicum were collected at the Herbário Ático Seabra of the Universidade Federal do Maranhão, São Luís - MA, Brazil, in July 2018. Samples from the stem of A. rosaeodora were collected in the Ducke Forest Reserve of the National Institute of Amazonian Research, located at Km 26 of the AM-010 Highway (Manaus-Itacoatiara) in the municipality of Manaus, Amazonas. All species were identified by the Herbarium Attic Seabra (UFMA) and a sample of each deposited species. The plant materials were transported to the Laboratory of Research and Application of Essential Oils (LOEPAV/UFMA) of the Federal University of Maranhão (UFMA), kiln dry FANEM 520 at $45^{\circ} \mathrm{C} / 24 \mathrm{~h}$. Subsequently, they were crushed in an electric mill and their mass measured for yield calculations.

\subsection{Extraction of EOs}

For extraction of EOs, the hydrodistillation technique was used with a glass Clevenger extractor coupled to a round-bottomed balloon packed in an electric blanket as a heat generating source. $122 \mathrm{~g}$ of $C$. citratus dry leaves, $100 \mathrm{~g}$ of $O$. basilicum and $30 \mathrm{~g}$ of $A$. rosaeodora were used adding distilled 
water (1:10). Hydrodistillation was conducted at $100^{\circ} \mathrm{C}$ for $3 \mathrm{~h}$ collecting the extracted EO. EO was dried with sodium sulfate $\left(\mathrm{Na}_{2} \mathrm{SO}_{4}\right)$. These operations were performed in triplicates and samples were stored in amber glass ampoules under $4^{\circ} \mathrm{C}$ refrigeration to avoid possible losses of volatile constituents.

\subsection{Chemical analysis}

The physicochemical parameters of the EOs were determined: density, solubility, color and appearance according to the Farmacopeia Brasileira [12] and the EO constituents were identified by gas chromatography coupled to mass spectrometry (GC-MS). $1.0 \mathrm{mg}$ of the sample was dissolved in $1000 \mu \mathrm{L}$ of dichloromethane (purity 99.9\%). The conditions of analysis were as follows: Method: Adams. M; Injected volume: $0.3 \mu \mathrm{L}$; Column: Capillary HP-5MS (5\% diphenyl, 95\% dimethyl polysiloxane ) (Equivalent DB-5MS or CP-Sil 8CB LB/MS), in dimensions (30 $\mathrm{m} \mathrm{x}$ $0.25 \mathrm{~mm}$ x $0.25 \mu \mathrm{m})$; Drag gas: $\mathrm{He}(99.9995) ; 1.0 \mathrm{~mL} / \mathrm{min}$; Injector: $280^{\circ} \mathrm{C}$, Split mode $(1: 10)$; Oven: $40^{\circ} \mathrm{C}\left(5.0 \mathrm{~min}\right.$.) up to $240^{\circ} \mathrm{C}$ at a rate of $4 \mathrm{oC} . \mathrm{min}-1$, from $240^{\circ} \mathrm{C}$ to $300^{\circ} \mathrm{C}(7.5 \mathrm{~min})$ at a rate of 8 oC.min-1 ); tT = $60.0 \mathrm{~min}$; Detector: EM1; EI $(70 \mathrm{eV})$; Scan mode $(0.5 \mathrm{sec} / \mathrm{scan})$; Mass range: 40 - 500 daltons (one); Line transfer: $280^{\circ} \mathrm{C}$; Filament: off 0.0 to $4.0 \mathrm{~min}$; Linear quadrupole mass spectrometer. The AMDIS (Automated Mass spectral Deconvolution Mass \& Identification System) program was used to identify the compounds in the sample. Chromatographic peaks were identified by comparing the respective mass spectra with the data of the spectrothecae (1) WILEY 139; (2) NIST107; (3) NIST21.

\subsection{Toxicity}

This test was performed according to the methodology described by Meyer et al. (1982) [13]. In a rectangular container, with a partition containing holes of approximately $0.02 \mathrm{~cm}$ thickness spaced by $0.5 \mathrm{~cm}$ and evenly distributed, artificial saline solution $\left(60 \mathrm{gL}^{-1}\right.$ of distilled water) were added $(60 \mathrm{~g}$ of sea salt/1L of distilled water). The container was placed inside an incubator illuminated by a fluorescent lamp, with aeration. On one side of this container, about $64 \mathrm{mg}$ of Artemia salina cysts were added, taking care that they did not cross the partition. The part of the system containing Artemia salina cysts was covered with aluminium foil, so that the organisms, at birth, were attracted by light on the other side of the system, forcing them to cross the partition. This procedure aims at homogenizing the physical conditions of the test organisms. Incubation was performed for a period of 48 hours. Throughout the test the temperature was monitored.

For the evaluation of the lethality of Artemia salina Leach, a saline solution stock of each EO was prepared in the concentration of $10.000 \mathrm{mgL}^{-1}$ and $0.02 \mathrm{mg}$ of Tween 80 (active tense). Rates of 5,50 and $500 \mu \mathrm{L}$ of this were transferred to test tubes and supplemented with saline solution previously prepared up to $5 \mathrm{~mL}$, obtaining at the end concentrations of 10,100 and $1000 \mathrm{mgL}^{-1}$, respectively. All tests were carried out in triplicates, where ten larvae in the nauplium phase were transferred to each of the test tubes.

For white, $5 \mathrm{~mL}$ of the saline solution was used for positive control $\mathrm{K}_{2} \mathrm{Cr}_{2} \mathrm{O}_{7}$ and for negative control $5 \mathrm{~mL}$ of a $4 \mathrm{mgL}^{-1}$ solution of Tween 80 . After 24 hours of exposure, the count of the live larvae was performed, considering dead those that did not move during observation or with the slight agitation of the vial. The criterion established by Dolabela (1997) [14] was adopted for classification of EOs toxicity, being considered highly toxic when $\mathrm{CL}_{50} \leq 80 \mathrm{mgL}^{-1}$, moderately toxic to $80 \mathrm{mgL}^{-1} \leq \mathrm{LC}_{50} \geq 250 \mathrm{mgL}^{-1}$ and slightly toxic or nontoxic when $\mathrm{LC}_{50} \geq 250 \mathrm{mgL}^{-1}$. Statistical analysis of the data for the toxicity test was performed according to the Reed and Muench (1938) [15] and the confidence interval according to Pizzi (1950) [16].

\subsection{Antimicrobial activity}

Two strains of bacteria were used: Escherichia coli (ATCC 25922) and Staphylococcus aureus (ATCC 25923). These were previously identified and confirmed by biochemical tests.

Pure microbial cultures maintained in Agar TSA were peaked for Brain and Heart Infusion Broth (BHI) and incubated at $35^{\circ} \mathrm{C}$ until they reached exponential growth phase (4-6h). After this period, the cultures had their cell density adjusted in $0.85 \%$ sterile saline solution, in order to obtain 
turbidity comparable to that of the standard McFarland solution 0.5 , which results in a microbial suspension containing approximately $1.5 \times 10^{8} \mathrm{CFUmL}^{-1}$.

Antimicrobial activity was performed according to the disc diffusion technique of the Clinical and Laboratory Standards Institute (2015) [17] that standardizes antimicrobial sensitivity tests by disc-diffusion, using standardized suspensions of E. coli (ATCC 25922) and S. aureus (ATCC 25923) strains distributed in plates containing Agar Mueller Hinton (AMH) culture medium plus discs containing $50 \mu \mathrm{L}$ of EO. Gentamycin $(30 \mu \mathrm{g})$ was used as positive control. The plates were incubated in a bacteriological greenhouse at $35^{\circ} \mathrm{C}, 24 \mathrm{~h}$. Inhibition halo diameters were measured, including disc diameter. These trials were done in triplicate.

To determine the Minimum Inhibitory Concentration (MIC), the dilution technique was used in broth. With serial EO dilutions in Broth Mueller Hinton (BMH), resulting in concentrations of $1000,500,250,100,50,25,10$ and $5 \mu \mathrm{gmL}^{-1}$, performing sterility controls and incubation at $35^{\circ} \mathrm{C}$ for $24 \mathrm{~h}$. After the incubation period, MIC was verified, being defined as the lowest concentration that visibly inhibited bacterial growth (absence of visible cloudiness). Trials were carried out in triplicate. The Minimum Bactericidal Concentration (MBC) was measured from the inoculation of $10 \mu \mathrm{L}$ of the tubes resulting from dilution in $\mathrm{BMH}$, performed in a plate count after $24 \mathrm{~h}$, where plaques that did not grow colonies were classified as bactericidal concentrations for the action of the EO.

\section{RESULTS AND DISCUSSION}

\subsection{Physicochemical parameters}

Physicochemical determinations of density, refractive index and solubility are presented in Table 1. According to the results expressed in Table 1, a yield of $2.1 \%$ was obtained for the EO of C. citratus, for the $\mathrm{OE}$ extracted from the leaves of $O$. basilicum $0.38 \%$ and for A. rosaeodora $1.87 \%$.

Table 1: Physicochemical parameters of the Eos.

\begin{tabular}{cccccc}
\hline EO & Density & $\begin{array}{c}\text { Refractive } \\
\text { index }\end{array}$ & $\begin{array}{c}\text { Solubility } \\
\text { EtOH 70\% }\end{array}$ & Color & Yield \\
\hline C. citratus & $\begin{array}{c}0.8560 \pm 0,0070 \\
(\mathrm{~g} \mathrm{~mL}-1)\end{array}$ & $\begin{array}{c}1.5200 \pm 0,0035 \\
\left(\mathrm{nD} 25^{\circ}\right)\end{array}$ & $\begin{array}{c}1: 2 \\
(\mathrm{v} / \mathrm{v})\end{array}$ & Yellow & $2.10 \% \pm 0,15$ \\
O. basilicum & $\begin{array}{c}0.9396 \pm 0,0031 \\
(\mathrm{~g} \mathrm{~mL}-1)\end{array}$ & $\begin{array}{c}1.4980 \pm 0,0177 \\
\left(\mathrm{nD} 25^{\circ}\right)\end{array}$ & $\begin{array}{c}1: 2 \\
(\mathrm{v} / \mathrm{v})\end{array}$ & Yellow & $0.38 \% \pm 0,03$ \\
A. rosaeodora & $\begin{array}{c}0.8660 \pm 0,0087 \\
\left(\mathrm{~g} \mathrm{~mL}^{-1}\right)\end{array}$ & $\begin{array}{c}1.4660 \pm 0,0554 \\
\left(\mathrm{nD} \mathrm{25^{ \circ }}\right)\end{array}$ & $\begin{array}{c}1: 2 \\
(\mathrm{v} / \mathrm{v})\end{array}$ & Yellow & $1.87 \% \pm 0,18$ \\
\hline
\end{tabular}

These physicochemical parameters are essential factors to ensure the quality and purity of the EOs studied, being extremely relevant for applications to observe the individual yield of each EO. In the study conducted by Pinto et al. (2015) [18] the EO yield of $C$. citratus varied between $1.8 \%$ and $2.6 \%$, since this result is affected by factors such as the crop region and seasonality [19], and the yield of this EO was reported in this study was within the reported range by the author. Studies report that when this plant is obtained in the periods of the year with higher rainfall index and high temperature, they present higher OE yield, when compared to other seasons of the year [20].

Previous studies show a significant variation in EO production of $O$. basilicum. According to the study by Al-Maskria et al. (2011) [21], the yield of this EO ranged from $0.1 \%$ to $0.3 \%$ according to the season. Beatović et al. (2015) [22] reported EO yields between $0.65 \%$ and $1.9 \%$, justifying the large variation in levels to the detriment of agroclimatic differences and cultivation techniques. Pravuschi et al. (2010) [23] observed that there was an increase in the yield of this EO from the third harvest of plant material, since the cut of inflorescences can stimulate and increase the concentration of EOs in the remaining leaves of the plant. The low EO yield of this study can be attributed to the climatic conditions in which the plant in question was submitted, since the high temperatures of the state of Maranhão, during the period in which it was collected, benefited the early evaporation of volatile compounds from the plant. This phenomenon was observed in the 
study by Hussain et al. (2008) [24], where EO yield was significantly lower in the Pakistani summer, ranging from 30 to $40^{\circ} \mathrm{C}$.

The value obtained for the EO yield of A. rosaeodora in this research was higher than the result found by May et al. (2004) [25] and Amazonas (2012) [26] where they report that EO yield can range from 1 to $1.2 \%$. However, according to Takeda (2008) [27], the yield of EO A. rosaeodora ranges from $2.24 \%$ for branches and $3.37 \%$ for leaves in five-year planting, making them potential for industrial production. In the present study, the EO was extracted from the stem and presented a considerable income, which encourages its extraction and application.

\subsection{Chemical constituents}

Table 2 presents the constituents identified in the EO of $C$. citratus. They were identified in the EO as geranial majority compounds ( $\alpha$-citral) with $43.96 \%$, followed by neral ( $\beta$-citral) with $35.71 \%$ and oxidized epoxy-linalool oxide with $8.61 \%$.

Table 2: Chemical constituents identified in the EO of Cymbopogon citratus.

\begin{tabular}{cccc}
\hline Order & RT & Components & \% \\
\hline 2 & 4.350 & $\beta$-myrcene & 2.71 \\
5 & 6.043 & linalool & 0.90 \\
8 & 8.367 & neral & 35.71 \\
10 & 8.875 & geranial & 43.96 \\
11 & 9.100 & epoxy-linalool oxide & 8.61 \\
12 & 10.174 & isoamyl geranate & 0.56 \\
14 & 19.053 & methyl geranate & 0.77 \\
19 & 20.090 & cyclopropanemethanol & 0.31 \\
\hline \multicolumn{3}{c}{ Other } & 6.47 \\
\hline
\end{tabular}

Chemical studies of $C$. citratus in different habitats around the world identified citral as the main volatile constituent, which is a mixture of isomers, geranial ( $\alpha$-citral), and neral ( $\beta$-citral) [18]. The chemical composition for the EO of $C$. citratus is in accordance with that observed in several studies. Sacchetti et al. (2005) [28] reported the presence of 65 to $86 \%$ citral in the EO of this species. In more recent studies, Lucena et al. (2015) [29] found levels of neral $43.69 \%$ and $34.05 \%$ geranial, and Gonçalves et al. (2015) [9] reported the presence of geranial (46.32\%) and neral (31.28\%) values similar to those found in OE C. citratus analysis in this study.

It is noteworthy that both fresh and dry leaves of $C$. citratus are used for the purpose of obtaining $\mathrm{EO}$, where the yield of the $\mathrm{EO}$ is 0.28 to $0.50 \%$ of fresh mass. The authors recommend that the harvest of $C$. citratus be performed at 08:00 to 13:00 h when a higher citral concentration is observed, because high temperatures influence the quality of EO [30]. The differences observed in the quantity and chemical composition of the EOs of plants of the same species in different regions can be caused by microclimatic, phytogeographic, genotypic and geographical and agronomic conditions, mainly in the soil. However, as a general rule, the main components remain the same, varying only their concentration levels [22].

Table 3 presents the constituents identified in EO O. basilicum. In the OE was identified as the majority constituent the methyl chavicol with $62.39 \%$ followed by linalool $(25.88 \%)$ and $\alpha$ farnesene $(6.14 \%)$.

Table 3: Chemical composition of EO Ocimum basilicum.

\begin{tabular}{cccc}
\hline Order & RT & Components & \% \\
\hline 1 & 15.66 & Eucalyptol & 3.48 \\
2 & 18.50 & Linalool & 25.88 \\
3 & 21.32 & $\alpha$-terpineol & 1.43 \\
4 & 22.16 & methyl chavicol & 62.39 \\
5 & 20.12 & $($ E,E)- $\alpha$-farnesene & 6.14 \\
6 & 36.21 & $\alpha$-cadinol & 0.67 \\
\hline
\end{tabular}


For EO O. basilicum, similar results were described by Joshi (2014) [32], who reported that of the 25 compounds characterized and identified by CG/MS, $38.3 \%$ of the EO obtained was composed of methyl chavicol, followed by $39.9 \%$ methyl eugenol. In the study by Beatović et al. (2015) [22], EO O. basilicum of the genotype Siam Queen presented methyl chavicol in $83.6 \%$ of its composition. The methyl chavicol also presented itself as majoritarian in the OE of Iranian $O$. basilicum reported by Sajjadi (2006) [33].

However, the linalool content of the EO of the present study was lower than those found by Carović-Stanko et al. (2010) [34] and Al-Abbasy et al. (2015) [35] where the percentages were $66.40 \%$ and $69.86 \%$, respectively. This result can be explained by seasonality and plant genotype collected in this study. The third majoritarian compound, $\alpha$-farnesene $(6.14 \%)$ was not found in any variation of $O$. basilicum of the study of Carović-Stanko et al. (2010) [34] and in any of the articles mentioned above. In the work of Labra et al. (2004) [36], the farnesene content ranged from 6.97 to $13.53 \%$ to the detriment of environmental and genetic factors. In the work of Calín-Sánchez et al. (2012) [37], the concentrations of $\alpha$-farnesene were affected by convective drying temperatures, presenting higher levels in the extraction of the fresh plant.

Table 4 presents the constituents identified in the $\mathrm{OE}$ of $A$. rosaeodora. In the $\mathrm{OE}$ of $A$. rosaeodora, 3 chemical components were identified as shown in Table 4, and its majority constituent linalool was identified, with a content of $93.60 \%$.

Table 4: Chemical constituents identified in EO Aniba rosaeodora.

\begin{tabular}{cccc}
\hline Order & RT & Components & \% \\
\hline 1 & 8.361 & $\alpha$-terpinolene & 3.37 \\
2 & 8.702 & cis-linalool oxide (furanoid) & 3.03 \\
3 & 9.177 & Linalool & 93.60 \\
\hline
\end{tabular}

The linalool content found in the EO of A. rosaeodora was higher than that found in the EO of the study by Cansian et al. (2010) [10] when analyzing Cinnamomum camphora and observing a percentage of $91.98 \%$ linalool. In this sense, EO A. rosaeodora is promising as a source of linalool.

Teles et al. (2018) [38] identified 9 chemical components present in the EO of A. rosaeodora by CG-MS, they are: linalool (89.34\%), $\alpha$-terpinolene $(3.06 \%)$ and cis-linalool oxide $(1.94 \%)$, elements also found in this EO, but with higher percentages. Cunha et al. (2011) [39] verified the seasonal influence of linalool present in the leaves and branches of EO A. rosaeodora. Based on the analyses performed through CG and CG-MS, it was possible to identify $76.69 \%$ linalool present in the EO even with the variations of harvest and climate time. These results were reaffirmed by Pimentel et al. (2018) [40] with GC-MS analysis of EO extracted from leaves and branches of $A$. rosaeodora Ducke collected in rainy and dry seasons showed quantitative and qualitative differences in chemical compositions. A total of 15 compounds were found in the $\mathrm{EO}$ of the leaves during the rainy season, while the EOs of the branches contained 11 compounds. Confirming the presence of a large number of chemical constituents in this $\mathrm{OE}$.

Based on the chemical compositions of the $\mathrm{EO}$ of A. rosaeodora, it is possible to realize that linalool is the majority compound of this EO with a variation of 71 to $84 \%$. However, in this study, a percentage of $93.60 \%$ was found, presenting as the highest in the literature.

\subsection{Antimicrobial activity}

Table 5 presents the results obtained for antimicrobial assays.

By the classification of Moreira et al. (2005) [41], the bacteria tested in this study were sensitive to the action of the EOs when they present inhibition halos greater than $9 \mathrm{~mm}$. Thus, it was possible to verify that $E$. coli and $S$. aureus present sensitivity to the action of all EOs tested.

The two strains tested were sensitive to the action of EO $C$. citratus, presenting the largest inhibition halos (25 mm for E. coli and $25 \mathrm{~mm}$ for $S$. aureus) compared to other tested EOs. According to Table 5, the OE C. citratus presented lower MIC for S. aureus, compared to E. coli, making it a potential for the control of these pathogenic microorganisms [42]. 
Studies reveal that EOs possessing as majority components, terpenes and monoterpenes, such as geranial, methyl chavicol and linalool, can destroy the cellular integrity of microorganisms by inhibiting the cell breathing process microbial membrane [43] and the disruption of the cytoplasmic membrane of these [44].

Table 5: Diameter of inhibition halos ( $\mathrm{mm}), \mathrm{MIC}\left(\mu \mathrm{g} \mathrm{LL}^{-1}\right)$ and $M B C\left(\mu \mathrm{g} \mathrm{L}^{-1}\right)$ for action of EOs against tested microorganisms.

\begin{tabular}{ccccc}
\hline EO & Microorganisms & DIH $(\mathbf{m m})$ & MIC $\left(\mathbf{u g ~} \mathbf{~ m}^{-1}\right)$ & MBC $\left(\mathbf{u g ~} \mathbf{~ m L}^{-1}\right)$ \\
\hline \multirow{2}{*}{ C. citratus } & E. coli & $25 \pm 2,20$ & $50(40-60)$ & $290(270-310)$ \\
& S. aureus & $25 \pm 1,30$ & $25(23-27)$ & $200(180-220)$ \\
O. basilicum & E. coli & $18 \pm 1,70$ & $100(90-110)$ & $320(300-340)$ \\
& S. aureus & $20 \pm 2,50$ & $50(45-55)$ & $200(175-225)$ \\
A. rosaeodora & E. coli & $11 \pm 3,20$ & $200(150-250)$ & $450(410-490)$ \\
& S. aureus & $15 \pm 3,10$ & $150(140-160)$ & $300(290-310)$ \\
\hline
\end{tabular}

The data regarding MIC and MBC obtained in the current study demonstrated that EO $O$. basilicum bears similarity to those reported by Trajan et al. (2009) [45]. According to the data contained in Table 5, it is possible to conclude that EO O. basilicum had more effective inhibitory action against $S$. aureus, since it presented smaller MIC and MBC than the E. coli front test. In addition, the results of the MIC and MBC were in accordance with the literature [46, 47].

According to the results shown in Table 5, it was possible to observe that The EO of $A$. rosaeodora presented the smallest inhibition halos against the two bacteria and the largest MIC and MBC, compared to the other EOs. However, as much as it has been the least effective compared to other EOs, its antimicrobial profile meets the inhibition criteria of natural products [41].

The low toxicity observed in the EOs in this study is directly related to the great potential to use these products as flavoring agents in food, beverages, confectionery products, among others, as possible natural agents for the conservation of food [42]. The factors that influence the toxicity of EOs are related to the chemical composition plant, the dose used and the form of use [48].

\subsection{Toxicity}

Figure 1 presents the dead and living accumulated curve of Artemia salina in front of the action of the EO of $C$. citratus, where it was possible to observe the intersection of curves at 2.75 and $\mathrm{LC}_{50}$ in $582 \mathrm{mg} \mathrm{L}^{-1} \pm 3.41 \mathrm{mg} \mathrm{L}^{-1}$, by ${ }^{14}$ is classified as nontoxic.

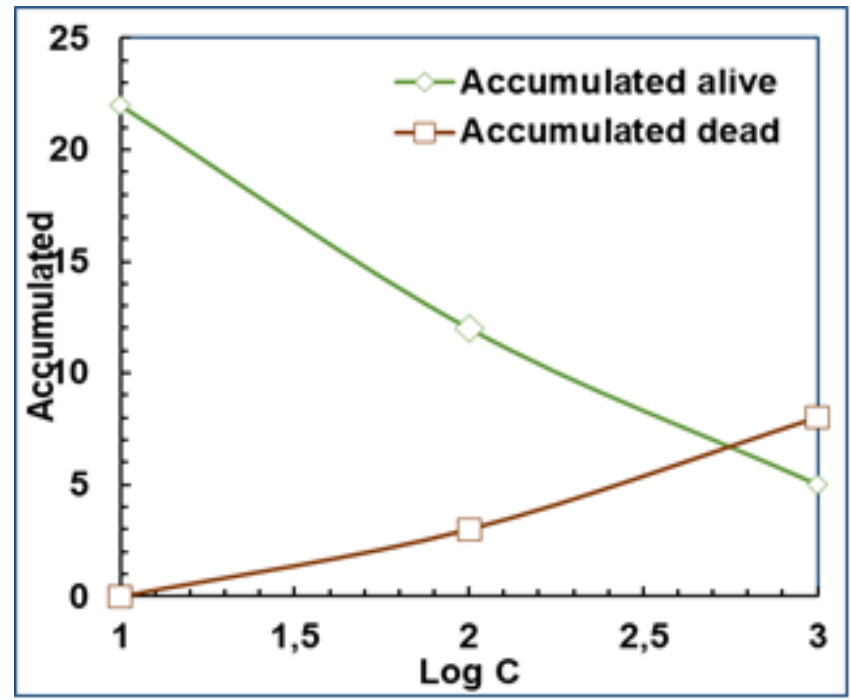

Figure 1: Accumulated curve of dead and alive Artemia salina versus EO Cymbopogon citratus concentration log. 
Similar results regarding EO C. citratus toxicity were reported by Prakash et al. (2016) [49] evaluating the toxicity of the methanolic extract of six medicinal plants by the bioassay of Artemia salina. The authors obtained $\mathrm{CL}_{50} 704.67 \pm 31.44 \mu \mathrm{g} \mathrm{mL} \mathrm{m}^{-1}$ for $C$. citratus extract being thus classified as nontoxic. De Lima et al. (2017) [50] investigated the EO toxicity of C. citratus by determining the Lethal Dose $50 \%$ ( $\mathrm{DL}_{50}$ ) in mice, it was observed that when receiving orally doses between 2000 and $4000 \mathrm{mg} \mathrm{kg}^{-1}$ of the $\mathrm{EO}$ of $C$. citratus, the value of the $\mathrm{LD}_{50}$ corresponded to $3000 \pm 91.32 \mathrm{mg} \mathrm{kg}^{-1}$ of body mass, classifying the EO as a substance of low toxicity [51]. Discordant results were reported by Füller (2013) [52] who observed high EO toxicity of $C$. citratus obtaining a $\mathrm{LC}_{50}$ of $20 \mathrm{ug} \mathrm{\textrm {mL } ^ { - 1 }}$.

Thus, it is possible to observe that the toxicity test is an indispensable tool for assessing or predicting the effects of toxic substances on biological systems and ascertaining the relative toxicity of substances that are predominant in environmental assessment [53]. In this sense this assay has been used to verify the toxicity of several plants $[54,55]$.

Figure 2 presents the dead and living accumulated curve of Artemia salina in front of the action of the EO of $O$. basilicum, where it was possible to observe the intersection of curves at 2.55 and $\mathrm{LC}_{50}$ in $355 \mathrm{mg} \mathrm{L}^{-1} \pm 3.25 \mathrm{mg} \mathrm{L}^{-1}$, by ${ }^{14}$ it is classified as nontoxic.

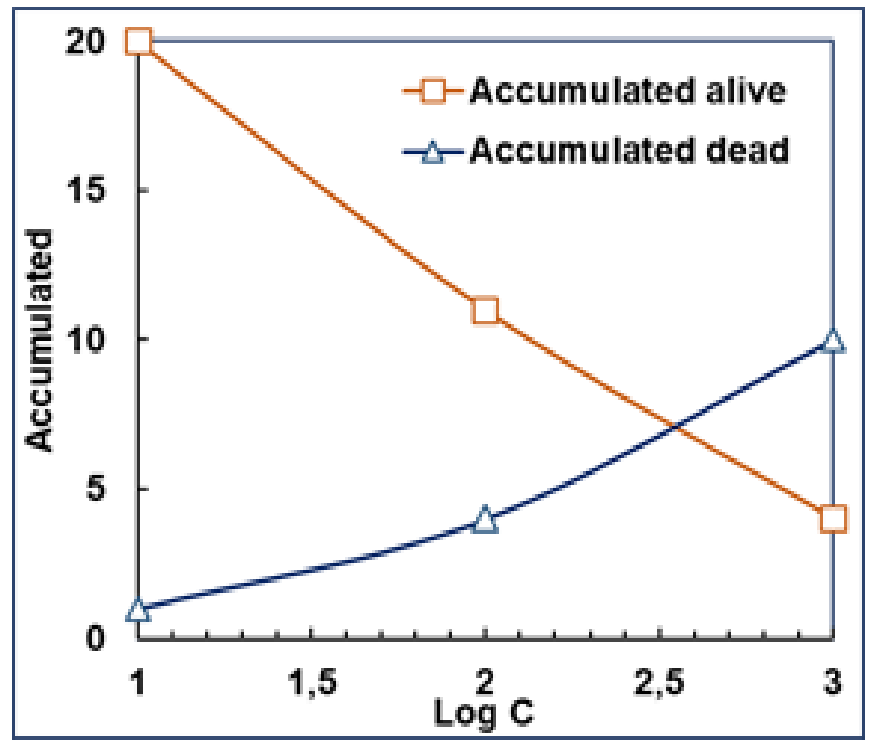

Figure 2: Accumulated curve of dead and alive Artemia salina versus EO Ocimum basilicum concentration $\log$.

The reported results for EO $O$. basilicum toxicity was consistent with those reported by Sharopov et al. (2016) [56], where EO presented active lethality against Artemia salina. Hamidi et al. (2014) [57] and Silva et al. (2010) [58] find a $\mathrm{LC}_{50}$ of $9.92 \mathrm{mg} \mathrm{mL}^{-1}$ and 233.8 (200.7-272.0) $\mu \mathrm{g}$ $\mathrm{mL}^{-1}$, respectively, stating moderate EO toxicity. Parra et al. (2001) [59] also reported high toxicity of $O$. basilicum extract (LC50 $9.92 \mu \mathrm{g} \mathrm{mL}^{-1}$ ). The high toxicity of the previously mentioned studies was attributed to the synergistic effects among their chemical components. In this study, EO showed little toxic due to its singular chemical profile, where lower linalool values and mostly methyl-chavicol were found. It is believed that the low concentration of other possibly toxic chemical assets in the EO of this study has caused its nontoxicity.

Figure 3 presents the dead and living accumulated curve of Artemia salina in front of the action of the EO of A. rosaeodora, where it was possible to observe the intersection of curves at 2.45 and $\mathrm{LC}_{50}$ in $282 \mathrm{mg} \mathrm{L}^{-1} \pm 2.95 \mathrm{mg} \mathrm{L}^{-1}$, by ${ }^{14}$ is classified as nontoxic. 


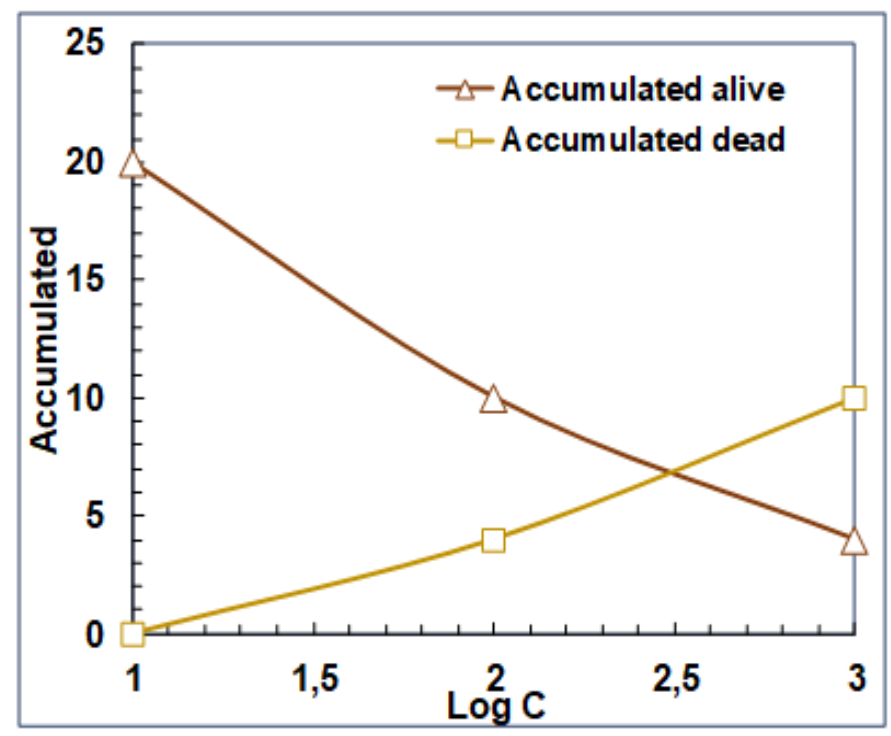

Figure 3: Accumulated curve of dead and alive Artemia salina versus OE Aniba rosaeodora concentration $\log$.

Studies in the literature on toxicity by the bioassay of Artemia salina Leach in front of the EO of $A$. rosaeodora are still scarce and poorly disclosed. Therefore, the results regarding toxicity were compared to studies with linalool as a major component. Ramos et al. (2017) [60] used gas chromatography coupled to mass spectrometry (GC/MS) and identified linalool (51.8\%) as a major component of EO Mentha piperita L. and in the evaluation of toxicity by Artemia salina bioassay obtained $\mathrm{LC}_{50} 414.6 \mu \mathrm{g} \mathrm{mL}{ }^{-1}$ classifying EO as nontoxic.

The chemical composition correlates the majority of linalool compound, as nontoxic being used in the medical area, justifying the result found of the classification of the same. Fujiwara et al. (2017) [61] verified the toxicity of linalool by the bioassay of primary in vitro toxicity of Artemia salina obtaining the $\mathrm{LC}_{50} 275.2 \mu \mathrm{g} \mathrm{mL}^{-1}$ classifying the linalool compound as nontoxic. Similar results were also observed by Brasil et al. (2009) [62] when analyzing the EO of Croton palanostigma trunk bark, whose linalool was the majority component and through the bioassay of Artemia salina verified a $\mathrm{LC}_{50} 371 \mu \mathrm{g} \mathrm{mL} \mathrm{m}^{-1}$, confirming EO toxicity used. Goel et al. (2019) [63] state that linalool is nontoxic, thus confirming applicability as a tool for manipulation in cancer cells, because it has a cytostatic effect [64]. It is concluded then that nontoxic EOs may also have a relative efficiency in antimicrobial properties in contrast to what was stated by MacBae et al. (1988) [65], where the authors report that the higher the toxicity the better the properties antimicrobials of the $\mathrm{OE}$.

\section{CONCLUSIONS}

The EOs showed satisfactory results against the microorganisms tested, revealing their efficiency in the fight and control of pathogenic microorganisms.

\section{ACKNOWLEDGEMENTS}

The authors thank the Laboratório de Pesquisa e Aplicação de Óleos Essenciais (LOEPAV/UFMA).

\section{REFERENCES}

1. Tamm L, Thürig B, Fliessbach A, Goltlieb AE, Karavani S, Cohen Y. Elicitors and soil management to induce resistance against fungal plant diseases. NJAS-Wagen J Life Sci. 2011 Dec;58(3-4):131-137, doi.org/10.1016/j.njas.2011.01.001

2. Ejike CE, Gong M, Udenigwe CC. Phytoalexins from the Poaceae: Biosynthesis, function and prospects in food preservation. Food Res Int. 2013 Jun;52(1):167-177, doi.org/10.1016/j.foodres.2013.03.012. 
3. Anjos, L. Estabelecimento e calogênese in vitro de Lippia alba (Mill) NE Brown (Verbenaceae) [monografia]. Salvador (BA): Universidade Federal da Bahia de Salvador; 2013.41 p.

4. Hirasa, K, Takemasa, M. Spice science and technology. New York: CRC Press; 1998.219 p.

5. Forsythe, SJ. Microbiologia da segurança dos alimentos. Porto Alegre: Artmed; 2013. 607 p.

6. Reis JB, de Figueiredo LA, Castorani GM, Veiga SMOM. Avaliação da atividade antimicrobiana dos óleos essenciais contra patógenos alimentares. Braz J Health Rev. 2020 Jan/Feb;3(1):342-363, doi: $10.34119 /$ bjhrv3n1-025

7. Costa DC, Costa HS, Albuquerque TG, Ramos F, Castilho MC, Sanches-Silva A. Advances in phenolic compounds analysis of aromatic plants and their potential applications. Trends Food Sci Technol. 2015 Oct;45(2):336-354, doi:10.1016/j.tifs.2015.06.009.

8. Tajkarimi MM, Ibrahim SA, Cliver DO. Antimicrobial herb and spice compounds in food. Food control. 2010 Sep;21(9):1199-1218, doi: 10.1016/j.foodcont.2010.02.003.

9. Gonçalves AH, Pereira AS, Santos GRS, Guimarães LGL. Atividade fungitóxica in vitro dos óleos essenciais de Lippia sidoides Cham., Cymbopogon citratus (DC) Stapf. e de seus constituintes majoritários no controle de Rhizoctonia solani e Sclerotium rolfsii. Rev Bras Pl Med. 2015 Apr;17(4): 1007-1015, doi: 10.1590/1983-084x/14_166.

10. Cansian RL, Mossi AJ, Oliveira DD, Toniazzo G, Treichel H, Paroul N, Serafini LA. Atividade antimicrobiana e antioxidante do óleo essencial de ho-sho (Cinnamomum camphora Ness e Eberm Var. Linaloolifera fujita). Food Sci Technol. 2010 Apr/Jun;30(2):378-384, doi: 10.1590/S010120612010000200014.

11. Martins AGLDA, Nascimento AR, Mouchrek Filho JE, Mendes Filho NE, Souza AG, Aragão NE, Silva DSVD. Atividade antibacteriana do óleo essencial do manjericão frente a sorogrupos de Escherichia coli enteropatogênica isolados de alfaces. Ciênc Rural. 2010 Aug;40(8):1791-1796, doi: 10.1590/S010384782010005000127

12. Farmacopeia Brasileira. São Paulo: Atheneu; 2010. 546 p.

13. Meyer BN, Ferrigni NR, Putnam JE, Jacobsen LB, Nichols DJ, McLaughlin JL. Brine shrimp: a convenient general bioassay for active plant constituents. Planta med. 1982 Jan;45(5):31-34, doi: 10.1055/s-2007-971236.

14. Dolabela ME. Triagem in vitro para a atividade antitumoral e anti-T. cruzi de extratos vegetais, produtos naturais e sintéticos [dissertação]. Belo Horizonte (MG): UFMG; 1997. 128 p.

15. Reed LJ, Muench H. A simple method of estimating fifty per cent endpoints. Am J Epidemiol. 1938 May;27(3):493-497, doi: 10.1093/oxfordjournals.aje.a118408.

16. Pizzi M. Sampling variation of the fifty per cent end-point, determined by the ReedMuench (Behrens) method. Hum Biol. 1950 Sep;22(3):151-190, doi: 10.2307/41447976.

17. Clinical and Laboratory Standards Institute (CLSI), Performance standards for antimicrobial disk susceptibility tests. Approved Standard Eleventh Edition; 2015. 32 p.

18. Pinto ZT, Sánchez FF, Santos ARD, Amaral ACF, Ferreira JLP, Escalona-Arranz JC, Queiroz MMDC. Chemical composition and insecticidal activity of Cymbopogon citratus essential oil from Cuba and Brazil against housefly. Rev Bras Parasitol Vet. 2015 Jan-mar;24(1):36-44, doi: 10.1590/S198429612015006.

19. Puppin DDGPB. Ação antifúngica e toxicidade do óleo essencial de Elionurus muticus (Capim-limão brasileiro) [dissertação]. Piracicaba: Universidade Estadual de Campinas; 2018. 50 p.

20. Furlan MR, Martins RCC, Rodrigues E, Scalco N, Negri G, Lago JHG. Variação dos teores de constituintes voláteis de Cymbopogon citratus (DC) Staf, Poaceae, coletados em diferentes regiões do Estado de São Paulo. Rev Bras Farmacogn. 2010 Oct/Nov;20(5):686-691, doi: 10.1590/S0102695X2010005000026.

21. Al-Maskri AY, Hanif MA, Al-Maskari MY, Abraham AS, Al-sabahi JN, Al-Mantheri O. Essential oil from Ocimum basilicum (Omani Basil): a desert crop. Nat Prod Commun. 2011;6(10):1487-1490, doi: 10.1177/1934578X1100601020.

22. Beatović D, Krstic-Milosevic D, Trifunovic S, Siljegovic J, Glamoclija J, Ristic M, Jelacic S. Chemical composition, antioxidant and antimicrobial activities of the essential oils of twelve Ocimum basilicum L. cultivars grown in Serbia. Rec Nat Prod. 2015 June;9(1):62-75.

23. Pravuschi PR, Marques PAA, Rigolin BHM, Santos ACP. Efeito de diferentes lâminas de irrigação na produção de óleo essencial do manjericão (Ocimum basilicum L.). Acta Sci-Agron. 2010 Oct/Dec;32(4):687-693, doi: 10.4025/actasciagron.v32i4.3160.

24. Hussain AI, Anwar F, Sherazi STH, Przybylski, R. Chemical composition, antioxidant and antimicrobial activities of basil (Ocimum basilicum) essential oils depends on seasonal variations. Food Chem. 2008 Jun;108(3):986-995, doi: 10.1016/j.foodchem.2007.12.010. 
25. May PH, Barata LE. Rosewood exploitation in the Brazilian Amazon: options for sustainable production. Econ Bot. 2004 Jun;58(2):257-265, doi: 10.1663/0013-0001(2004)058[0257: REITBA] 2.0.CO;2.

26. Amazonas DR. Variabilidade química e atividade antimicrobiana de espécimes indicados como pau-rosa (Aniba rosaeodora Ducke) do oeste do Pará [dissertação]. Santarém (PA): Universidade Federal do Pará; 2012. 20 p.

27. Takeda PS. Avaliação de biomassa e óleo de rebrotas de galhos e folhas de pau-rosa (Aniba rosaeodora Ducke) em plantios comerciais submetidos à poda e adubação [dissertação]. Manaus (AM): Univerdidade Federal da Amazônia; 2008.73 p.

28. Sacchetti G, Maietti S, Muzzoli M, Scaglianti M, Manfredini S, Radice M, Bruni R. Comparative evaluation of 11 essential oils of different origin as functional antioxidants, antiradicals and antimicrobials in foods. Food Chem. 2005 Jan/Mar;91(4):621-632, doi: 10.1590/S1984-29612015006.

29. Lucena BF, Tintino SR, Figueredo FG, Oliveira CDDM, Aguiar JJDS, Cardoso EDN, Matias EF. Avaliação da atividade antibacteriana e moduladora de aminoglicosídeos do óleo essencial de Cymbopogon citratus (DC.) Stapf. Acta Biol Colomb. 2015 Apr;20(1):39-45, doi: 10.15446/abc.v20n1.41673.

30. Nascimento ID, Innecco R, Marco CA, Mattos SH, Nagao EO. Efeito do horário de corte no óleo essencial de capim-santo. Ci Agron. 2003;34:169-172.

31. Pinto ZT, Sánchez FF, Santos ARD, Amaral ACF, Ferreira JLP, Escalona-Arranz JC, Queiroz MMDC. Chemical composition and insecticidal activity of Cymbopogon citratus essential oil from Cuba and Brazil against housefly. Rev Bras Parasit Vet. 2015 Jan/Mar;24(1):36-44, doi: 10.1590/S198429612015006.

32. Joshi RK. Chemical composition and antimicrobial activity of the essential oil of Ocimum basilicum L.(sweet basil) from Western Ghats of North West Karnataka, India. Ancient Sci Life. 2014 Jan-Mar; 33(3):151, doi: 10.4103/0257-7941.144618.

33. Sajjadi SE. Analysis of the essential oils of two cultivated basil (Ocimum basilicum L.) from Iran. DARU J Pharma Sci. 2006;14(3):128-130.

34. Carović-Stanko K, Orlić S, Politeo O, Strikić F, Kolak I, Milos M, Satovic Z. Composition and antibacterial activities of essential oils of seven Ocimum taxa. Food Chem. 2010 Mar;119(1):196-201, doi: 10.1016/j.foodchem.2009.06.010.

35. Al-Abbasy DW, Pathare N, Al-Sabahi JN, Khan SA. Chemical composition and antibacterial activity of essential oil isolated from Omani basil (Ocimum basilicum Linn.). Asian Pac J Trop Dis. 2015 Aug;5(8):645-649, doi: 10.1016/S2222-1808(15)60905-7.

36. Labra M, Miele M, Ledda B, Grassi F, Mazzei M, Sala F. Morphological characterization, essential oil composition and DNA genotyping of Ocimum basilicum L. cultivars. Plant Sci. 2004 Oct;167(4):725731, doi: 10.1016/j.plantsci.2004.04.026.

37. Calín-Sánchez Á, Lech K, Szumny A, Figiel A, Carbonell-Barrachina ÁA. Volatile composition of sweet basil essential oil (Ocimum basilicum L.) as affected by drying method. Food Res Int. 2012 Apr;48:217225.

38. Teles R.DM, Filho VEM, Mouchrek AN. Chemical Composition and Antibacterial Activity of Essential Oil of Aniba duckei Kosterman. Int J Life Sci Scienti Res. 2018;4(2):1657-1662. doi: 10.21276/ijlssr.2018.4.2.7

39. Da Cunha LN. Influência sazonal no teor de linalol do óleo essencial da Aniba duckei Kostermans cultivada em ambiente natural na reserva florestal Ducke. Ciên Nat. 2011 Jan;33(1):7-15.

40. Pimentel RB, Souza DP, Albuquerque PM, Fernandes AV, Santos AS, Duvoisin Jr S, Gonçalves JF. Variability and antifungal activity of volatile compounds from Aniba rosaeodora Ducke, harvested from Central Amazonia in two different seasons. Ind Crops Prod. 2018 Nov;123:1-9, doi: 10.1016/j.indcrop.2018.06.055.

41. Moreira MR, Ponce AG, Del Valle CE, Roura SI. Inhibitory parameters of essential oils to reduce a foodborne pathogen. LWT-Food Sci Technol. 2005 Aug;38(5):565-570, doi: 10.1016/j.1wt.2004.07.012.

42. Machado TF, Pereira R, Sousa CT, Batista VCV. Atividade antimicrobiana do óleo essencial do capim limão (Cymbopogon citratus) e sua interação com os componentes dos alimentos. Embrapa Agroind Trop. 2015 Jan/jun;33(1):30-38.

43. Helander IM, Alakomi HL, Latva-Kala K, Mattila-Sandholm T, Pol I, Smid EJ, von Wright A. Characterization of the action of selected essential oil components on Gram-negative bacteria. J Agr Food Chem. 1998 Aug;46(9):3590-3595, doi: 10.1021/jf980154m.

44. Bajpai VK, Sharma A, Baek KH. Antibacterial mode of action of seed essential oil of Eleutherococcus senticosus against foodborne pathogens. Int J Food Sci Tech. 2013 Jun;48(11):2300-2305, doi: 10.1111/ijfs.12217. 
45. Trajano VN, Lima EDO, Souza ELD, Travassos AER. Propriedade antibacteriana de óleos essenciais de especiarias sobre bactérias contaminantes de alimentos. Food Sci Technol. 2009 Jul/Sep;29(3):542-545, doi: 10.1590/S0101-20612009000300014.

46. Aquino LCLD, Santos GG, Trindade RDC, Alves JAB, Santos PO, Alves PB, Carvalho LMD. Atividade antimicrobiana dos óleos essenciais de erva-cidreira e manjericão frente a bactérias de carnes bovinas. Alim Nutr. 2010 Dez;21:529-535.

47. Freire ICM, Pérez ALAL, Cardoso AMR, Mariz BALA, Almeida LFD, Cavalcanti YW, Padilha WWN. Atividade antibacteriana de Óleos Essenciais sobre Streptococcus mutans e Staphylococcus aureus. Rev Bras Pl Med. 2014 Jan;16(2):372-377, doi: 10.1590/1983-084X/12_053 .

48. Campos SC, Silva CG, Campana PRV, Almeida VL. Toxicidade de espécies vegetais. Rev Bras Pl Med. 2016 Jan;18(1):373-382, doi: 10.1590/1983-084X/15_057.

49. Prakash S, Ramasubburayan R, Ramkumar VS, Kannapiran E, Palavesam A, Immanuel G. In vitroScientific evaluation on antimicrobial, antioxidant, cytotoxic properties and phytochemical constituents of traditional coastal medicinal plants. Biomed. Pharmacother. 2016 Oct;83:648-657, doi: 10.1016/j.biopha.2016.07.019.

50. De Lima AB, da Silva PIC, Junior JDCB, Cardoso AS, Silva LM, Silva RC, da Silva Freitas JJ. Avaliação toxicológica do óleo essencial de Cymbopogon citratus (DC) stapf (Capim-Marinho) em camundongos e ratos. Pará Res Med J. 2017 Jul;1(1):1-7, doi: 10.4322/prmj.2017.003.

51. OECD. Guideline for testing chemicals 425. Acute oral toxicity-up and down procedure. Paris: Organization for Economic Cooperation and Development; 2001. p. 12-16.

52. Füller TN. Caracterização genética e química e atividade biológica do óleo essencial de populações naturais de Elionurus muticus Humb. \& Bompl Ex Willd [dissertação]. Porto Alegre (RS): Universidade Federal Do Rio Grande Do Sul; 2013. 87 p.

53. Kpadonou Kpoviessi BG, Ladekan EY, Kpoviessi DS, Gbaguidi F, Yehouenou B, Quetin-Leclercq J, Accrombessi GC. Chemical variation of essential oil constituents of Ocimum gratissimum L. from Benin, and impact on antimicrobial properties and toxicity against Artemia salina Leach. Chem Biodivers. 2012 Jan;9(1):139-150, doi: 10.1002/cbdv.201100194.

54. Olivero-Verbel J, Gueette-Fernandez J, Stashenko E. Acute toxicity against Artemia franciscana of essential oils isolated from plants of the genus Lippia and Piper collected in Colombia. B. Latinoam Caribe Pl Med Aroma. 2009 Sep;8(5):419-427.

55. Ameen OM, Usman LA, Oladosu IA, Olawore NO, Ogunwande IA. Bioactivity of rhizome essential oils from two varieties of Cyperus articulatus (L.) grown in Nigeria, using brine shrimp (Artemia salina) lethality tests. J Med Plant Res. 2011 Mar;5(6):1031-1033.

56. Sharopov FS, Satyal P, Ali NAA, Pokharel S, Zhang H, Wink M, Setzer WN. The essential oil compositions of Ocimum basilicum from three different regions: Nepal, Tajikistan, and Yemen. Chem Biodivers. 2016 Feb;13(2):241-248, doi: 10.1002/cbdv.201500108.

57. Hamidi MR, Jovanova B, Panovska TK. Toxicological evaluation of the plant products using Brine Shrimp (Artemia salina L.) model. Maced Pharm Bull. 2014;60(1):9-18, doi: 10.33320/maced.pharm.bull.2014.60.01.002.

58. Silva LL, Heldwein CG, Reetz LG, Hörner R, Mallmann CA, Heinzmann BM. Composição química, atividade antibacteriana in vitro e toxicidade em Artemia salina do óleo essencial das inflorescências de Ocimum gratissimum L., Lamiaceae. Rev Bras Farmacogn. 2010 Aug;20(5):700-705, doi: 10.1590/S0102-695X2010005000010.

59. Parra AL, Yhebra RS, Sardiñas IG, Buela LI. Comparative study of the assay of Artemia salina L. and the estimate of the medium lethal dose (LD50 value) in mice, to determine oral acute toxicity of plant extracts. Phytomedicine 2001 Aug;8(5):395-400, doi: 10.1078/0944-7113-00044.

60. Da Silva Ramos R, Rodrigues ABL, Farias ALF, Simões RC, Pinheiro MT, Ferreira RMDA, de Almeida SSMD. Chemical composition and in vitro antioxidant, cytotoxic, antimicrobial, and larvicidal activities of the essential oil of Mentha piperita L. (Lamiaceae). Sci World J. 2017 Jan;1:1-8, doi: $10.1155 / 2017 / 4927214$.

61. Fujiwara GM, Annies V, de Oliveira CF, Lara RA, Gabriel MM, Betim FC, Miguel, MD. Evaluation of larvicidal activity and ecotoxicity of linalool, methyl cinnamate and methyl cinnamate/linalool in combination against Aedes aegypti. Ecotox. Environ Safe. 2017 May;139:238-244, doi: 10.1016/j.ecoenv.2017.01.046.

62. Brasil DDSB, Muller AH, Guilhon GMS, Alves CN, Andrade EHA, Silva JKRD, Maia JG. Essential oil composition of Croton palanostigma Klotzsch from north Brazil. J Braz Chem Soc. 2009 Jun;20(6):11881192, doi: 10.1590/S0103-50532009000600026.

63. Goel T, Wang R, Martin S, Lanphear E, Collins E.M.S. Linalool acts as a fast and reversible anesthetic in Hydra. PloS one. 2019 Oct;14(10): e0224221, doi: 10.1371/journal.pone.0224221. 
64. Rodenak-Kladniew B, Castro A, Stärkel P, De Saeger C, de Bravo MG, Crespo R. Linalool induces cell cycle arrest and apoptosis in HepG2 cells through oxidative stress generation and modulation of Ras/MAPK and Akt/mTOR pathways. Life Sci. 2018 Apr;199:48-59, doi: 10.1016/j.lfs.2018.03.006.

65. MacBae WD, Hudson JB, Towers GHN. Studies on the pharmacological activity of Amazonian Euphorbiaceae. J Ethnopharmacol. 1988 Feb-Mar;22(2):143-172, doi: 10.1016/0378-8741(88)90124-9. 